\title{
Front Matter: Volume 6815
}

, "Front Matter: Volume 6815," Proc. SPIE 6815, Document Recognition and Retrieval XV, 681501 (11 March 2008); doi: 10.1117/12.790909

SPIE. Event: Electronic Imaging, 2008, San Jose, California, United States 


\title{
PROCEEDINGS Electronic Imaging \\ Sclence and Tochnology
}

\section{Document Recognition and Retrieval XV}

\author{
Berrin A. Yanikoglu \\ Kathrin Berkner \\ Editors
}

29-31 January 2008

San Jose, California, USA

Sponsored and Published by

IS\&T-The Society for Imaging Science and Technology

SPIE

Cosponsored by

Ricoh Innovations, Inc. (USA) 
The papers included in this volume were part of the technical conference cited on the cover and title page. Papers were selected and subject to review by the editors and conference program committee. Some conference presentations may not be available for publication. The papers published in these proceedings reflect the work and thoughts of the authors and are published herein as submitted. The publishers are not responsible for the validity of the information or for any outcomes resulting from reliance thereon.

Please use the following format to cite material from this book:

Author(s), "Title of Paper," in Document Recognition and Retrieval XV, edited by Berrin A. Yanikoglu, Kathrin Berkner, Proceedings of SPIE-IS\&T Electronic Imaging, SPIE Vol. 6815, Article CID Number (2008).

ISSN 0277-786X

ISBN 9780819469878

\author{
Copublished by \\ SPIE \\ P.O. Box 10, Bellingham, Washington $98227-0010$ USA \\ Telephone +1 3606763290 (Pacific Time) · Fax +1 3606471445 \\ SPIE.org \\ and \\ IS\&T-The Society for Imaging Science and Technology \\ 7003 Kilworth Lane, Springfield, Virginia, 22151 USA \\ Telephone +1 7036429090 (Eastern Time) · Fax +1 7036429094 \\ imaging.org
}

Copyright (C) 2008, Society of Photo-Optical Instrumentation Engineers and The Society for Imaging Science and Technology.

Copying of material in this book for internal or personal use, or for the internal or personal use of specific clients, beyond the fair use provisions granted by the U.S. Copyright Law is authorized by the publishers subject to payment of copying fees. The Transactional Reporting Service base fee for this volume is $\$ 18.00$ per article (or portion thereof), which should be paid directly to the Copyright Clearance Center (CCC), 222 Rosewood Drive, Danvers, MA 01923. Payment may also be made electronically through CCC Online at copyright.com. Other copying for republication, resale, advertising or promotion, or any form of systematic or multiple reproduction of any material in this book is prohibited except with permission in writing from the publisher. The CCC fee code is 0277-786X/08/ $\$ 18.00$.

Printed in the United States of America.

Paper Numbering: Proceedings of SPIE follow an e-First publication model, with papers published first online and then in print and on CD-ROM. Papers are published as they are submitted and meet publication criteria. A unique, consistent, permanent citation identifier (CID) number is assigned to each article at the time of the first publication. Utilization of CIDs allows articles to be fully citable as soon they are published online, and connects the same identifier to all online, print, and electronic versions of the publication. SPIE uses a six-digit CID article numbering system in which:

- The first four digits correspond to the SPIE volume number.

- The last two digits indicate publication order within the volume using a Base 36 numbering system employing both numerals and letters. These two-number sets start with 00, 01, 02, 03, 04, 05, 06, 07, 08 , $09,0 A, O B \ldots O Z$, followed by 10-1Z, 20-2Z, etc.

The CID number appears on each page of the manuscript. The complete citation is used on the first page, and an abbreviated version on subsequent pages. Numbers in the index correspond to the last two digits of the six-digit CID number. 


\section{Contents}

vii Conference Committee

\section{SESSION 1 INVITED PRESENTATION}

681502 DRR is a teenager (Invited Paper) [6815-01]

G. Nagy, Rensselaer Polytechnic Institute (USA)

\section{SESSION 2 CLASSIFICATION AND RECOGNITION I}

681503 Recognition of Arabic handwritten words using contextual character models [6815-02]

R. El-Hajj, Univ. of Balamand (Lebanon) and GET-Ecole Nationale Supérieure des

Télécommunications (France); C. Mokbel, Univ. of Balamand (Lebanon);

L. Likforman-Sulem, GET-Ecole Nationale Supérieure des Télécommunications (France)

681504 Combining different classification approaches to improve off-line Arabic handwritten word recognition [6815-03]

I. Zavorin, E. Borovikov, E. Davis, A. Borovikov, K. Summers, CACl International Inc. (USA)

681505 Writer adaptation in off-line Arabic handwriting recognition [6815-04]

G. R. Ball, S. N. Srihari, Univ. at Buffalo (USA)

681506 Whole-book recognition using mutual-entropy-driven model adaptation [6815-05]

P. Xiu, H. S. Baird, Lehigh Univ. (USA)

\section{SESSION 3 IMAGE PROCESSING AND ENHANCEMENT}

681507 Interactive evolutionary computing for the binarization of degenerated handwritten images [6815-06]

T. van der Zant, L. Schomaker, A. Brink, Univ. of Groningen (Netherlands)

681508 Correlating degradation models and image quality metrics [6815-27]

D. K. Reed, E. H. Barney Smith, Boise State Univ. (USA)

681509 Ensemble LUT classification for degraded document enhancement [6815-08]

T. Obafemi-Ajayi, G. Agam, O. Frieder, Illinois Institute of Technology (USA)

$68150 \mathrm{~A}$ Automatic removal of crossed-out handwritten text and the effect on writer verification and identification [6815-10]

A. Brink, H. van der Klauw, L. Schomaker, Univ. of Groningen (Netherlands) 
6815 OB A mixed approach to book splitting [6815-11]

L. Gao, Z. Tang, Peking Univ. (China)

6815 OC Robust line segmentation for handwritten documents [6815-12]

K. Kuzhinjedathu, H. Srinivasan, S. Srihari, Univ. at Buffalo (USA)

6815 OD Line-touching character recognition based on dynamic reference feature synthesis [6815-13]

Y. Hotta, K. Fujimoto, Fujitsu Labs., Ltd. (Japan)

6815 OE Word segmentation of off-line handwritten documents [6815-14]

C. Huang, S. N. Srihari, Univ. at Buffalo (USA)

\section{SESSION $5 \quad$ INVITED PRESENTATION}

6815 OF The OCRopus open source OCR system (Invited Paper) [6815-15]

T. M. Breuel, Deutsches Forschungszentrum für Künstliche Intelligenz GmbH (Germany) and Univ. Kaiserslautern (Germany)

\section{SESSION 6 CLASSIFICATION AND RECOGNITION II}

6815 OG Measuring the impact of character recognition errors on downstream text analysis [6815-16]

D. Lopresti, Lehigh Univ. (USA)

$6815 \mathrm{OH} \quad$ Online writer identification using character prototypes distributions [6815-17] S. K. Chan, Univ. Tunku Abdul Rahman (Malaysia); C. Viard-Gaudin, Univ. de Nantes (France); Y. H. Tay, Univ. Tunku Abdul Rahman (Malaysia)

68150 Ol Stroke frequency descriptors for handwriting-based writer identification [6815-18] B. Dolega, G. Agam, S. Argamon, Illinois Institute of Technology (USA)

\section{SESSION 7 SEGMENTATION II}

6815 0J Address block localization based on graph theory [6815-19]

D. Gaceb, V. Eglin, F. Lebourgeois, H. Emptoz, Institut National des Sciences Appliquées de Lyon (France)

$68150 \mathrm{~K}$ Versatile page numbering analysis [6815-20]

H. Déjean, J.-L. Meunier, Xerox Research Ctr. Europe (France)

$6815 \mathrm{OL}$ Segmentation-based retrieval of document images from diverse collections [6815-21] M. A. Moll, H. S. Baird, Lehigh Univ. (USA)

$68150 \mathrm{M}$ Transcript mapping for handwritten English documents [6815-22]

D. Jose, A. Bharadwaj, V. Govindaraju, Univ. at Buffalo (USA) 
6815 ON Word mining in a sparsely labeled handwritten collection [6815-23]

L. R. B. Schomaker, Univ. of Groningen (Netherlands)

681500 An OCR based approach for word spotting in Devanagari documents [6815-24]

A. Bhardwaj, S. Kompalli, S. Setlur, V. Govindaraju, Univ. at Buffalo (USA)

6815 OP Extracting a sparsely located named entity from online HTML medical articles using support vector machine [6815-25]

J. Zou, D. Le, G. R. Thoma, National Library of Medicine (USA)

$68150 Q \quad$ Exploring use of images in clinical articles for decision support in evidence-based medicine [6815-26]

S. Antani, D. Demner-Fushman, National Library of Medicine (USA); J. Li, Univ. at Buffalo (USA); B. V. Srinivasan, Univ. of Maryland, College Park (USA); G. R. Thoma, National Library of Medicine (USA)

\section{INTERACTIVE PAPER AND SYMPOSIUM DEMONSTRATION SESSION}

6815 OR Model-based document categorization employing semantic pattern analysis and local structure clustering [6815-37]

K. Fume, Toshiba Corp. (Japan); Y. Ishitani, Toshiba Solutions Corp. (Japan)

6815 OS Large scale parallel document image processing [6815-28]

T. van der Zant, L. Schomaker, E. Valentijn, Univ. of Groningen (Netherlands)

6815 ОT A mixed approach to auto-detection of page body [6815-29]

L. Gao, Z. Tang, R. Qiu, Peking Univ. (China)

$68150 \mathrm{U}$ Extracting curved text lines using the chain composition and the expanded grouping method [6815-30]

N. Noi Bai, K. Nam, Chungbuk National Univ. (South Korea); Y. Song, Chungbuk BIT

Research-Oriented Univ. Consortium (South Korea)

$68150 \mathrm{~V}$ Achieving high recognition reliability using decision trees and AdaBoost [6815-31]

J. Xiang, X. Tu, Y. Lu, East China Normal Univ. (China); P. S. P. Wang, Northeastern Univ. (USA)

$68150 \mathrm{OW}$ A generic method for structure recognition of handwritten mail documents [6815-32]

A. Lemaitre, J. Camillerapp, B. Coüasnon, IRISA/INSA (France)

6815 OX Hybrid approach combining contextual and statistical information for identifying MEDLINE citation terms [6815-33]

I. C. Kim, D. X. Le, G. R. Thoma, National Library of Medicine (USA)

6815 OY Form classification [6815-34]

K. V. U. Reddy, V. Govindaraju, Univ. at Buffalo (USA) 
$68150 Z$ Interactive degraded document enhancement and ground truth generation [6815-35] G. Bal, G. Agam, O. Frieder, Illinois Institute of Technology (USA); G. Frieder, George Washington Univ. (USA)

681510 Efficient implementation of local adaptive thresholding techniques using integral images [6815-36]

F. Shafait, D. Keysers, German Research Ctr. for Artificial Intelligence (Germany);

T. M. Breuel, Technical Univ. of Kaiserslautern (Germany)

Author Index 


\title{
Conference Committee
}

\author{
Symposium Chair \\ Nitin Sampat, Rochester Institute of Technology (USA) \\ Conference Chairs
}

Berrin A. Yanikoglu, Sabanci University (Turkey)

Kathrin Berkner, Ricoh Innovations, Inc. (USA)

Program Committee

Tim L. Andersen, Boise State University (USA)

Apostolos Antonacopoulos, University of Salford (United Kingdom)

Elisa H. Barney-Smith, Boise State University (USA)

Xiaoqing Ding, Tsinghua University (China)

David S. Doermann, University of Maryland, College Park (USA)

Jianying Hu, IBM Thomas J. Watson Research Center (USA)

Matthew F. Hurst, Intelliseek, Inc. (USA)

Hisashi Ikeda, Hitachi, Ltd. (Japan)

Tapas Kanungo, Yahoo! Inc. (USA)

Laurence Likforman-Sulem, GET-École Nationale Supérieure des Télécommunications (France)

Xiaofan Lin, Riya Inc. (USA)

Daniel P. Lopresti, Lehigh University (USA)

Lambert R. B. Schomaker, University of Groningen (Netherlands)

Sargur N. Srihari, University at Buffalo (USA)

Venkata Subramaniam, IBM India Research Laboratory (India)

Kazem Taghva, University of Nevada, Las Vegas (USA)

George R. Thoma, National Library of Medicine (USA) 
Downloaded From: https://www.spiedigitallibrary.org/conference-proceedings-of-spie on 26 Apr 2023

Terms of Use: https://www.spiedigitallibrary.org/terms-of-use 